\title{
PENERAPAN PEMBELAJARAN KOOPERATIF TIPE NUMBER HEAD TOGETHER (NHT) UNTUK MENINGKATKAN KEMANDIRIAN BELAJAR SISWA KELAS VIII SMP NEGERI 1 SIAK HULU
}

\author{
Astri Wahyuni ${ }^{1}$ \\ ${ }^{1}$ Program Studi Pendidikan Matematika, FKIP, Universitas Islam Riau \\ e-mail : astriwahyuni@edu.uir.ac.id
}

\begin{abstract}
ABSTRAK
Penelitian ini bertujuan untuk meningkatkan self-efficacy siswa kelas VIII MTS YKWI Pekanbaru melalui Penelitian ini bertujuan untuk memperbaiki proses pembelajaran dan meningkatkan kemandirian belajar matematika siswa melalui Penerapan Pembelajaran Kooperatif Tipe Number Head Together (NHT). Penelitian

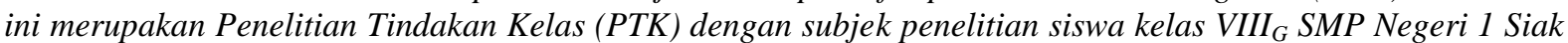
Hulu Tahun Ajaran 2015/2016 pada materi kubus dan balok. Teknik pengumpulan data pada penelitian ini adalah dengan menggunakan teknik pengamatan dan teknik angket. Sedangkan instrumen penelitian yang digunakan adalah lembar observasi dan angket kemandirian belajar. Hasil penelitian ini menunjukkan bahwa terjadi peningkatan proses pembelajaran di kelas yang ditandai dengan meningkatkatnya aktivitas belajar siswa pada lembar observasi. Peningkatan kemandirian belajar matematika siswa dapat dilihat dari skor dasar ke UH I, dari UH I ke UH II. Persentase kemandirian belajar siswa pada UH I adalah 52,61\% dan pada UH II 75,29\%. Berdasarkan hasil penelitian ini, maka dapat disimpulkan bahwa penerapan penerapan pembelajaran kooperatif tipe NHT dapat meningkatkan proses pembelajaran dan kemandirian belajar matematika siswa kelas VIII $_{G}$ SMP Negeri 1 Siak Hulu Tahun Ajaran 2015/2016
\end{abstract}

Kata kunci :

Kemandirian Belajar Matematika ; Numbered Head Together (NHT)

\section{ABSTRACT}

This research aim to improve the learning process and mathematics learning independence of the students through the Application of Cooperative Learning type Number Head Together (NHT). This research is a Classroom Action Research with research subject of class VIII ${ }_{G}$ of SMP Negeri 1 Siak Hulu 2015/2016 Academic Year on cube and beam material. Data collection technique used observation and questionnaire techniques. While the research instruments used observation sheets and learning independence questionnaires. The results of the research show there is an increase in the learning process in the class which is characterized by increasing student learning activities on the observation sheet. Increasing mathematics learning independence of the students can be seen from the basic score to daily exam I, from daily exam I to daily exam II. The percentage of student learning independence in daily exam I was 52.61\% and in daily exam II 75.29\%. Based on the results of this research, it can be concluded that the application of NHT cooperative learning can improve the learning process and the independence of mathematics learning of class VIII ${ }_{G}$ students of SMP Negeri 1 Siak Hulu, 2015/2016 Academic Year.

Keywords :

Numbered Heads Together

\section{PENDAHULUAN}

Pada tahun 2013, Indonesia menduduki peringkat ke-108 dari 187 negara. Jika dibandingkan dengan peringkat negara tetangga lainnya: Singapura (9), Brunei Darussalam (30), Malaysia (62), dan Thailand (89), maka negara kita belum mencapai peringkat lima teratas se-Asia Tenggara dari hal life expectancy, literacy, education, dan standards of living. Pada posisi puncak, negara-negara maju saling bersaing seiring bersaingnya prestasiprestasi yang telah mereka ukir. Suatu hal yang wajar apabila persaingan global memiliki hubungan yang berbanding lurus dengan sumber daya manusia. Artinya, semakin kompleks dan ketatnya persaingan global akan menuntut peningkatan kualitas sumber daya manusianya pula.

Bermunculannya berbagai teknologi dan inovasi teknologi menjadi bukti bahwa negara-negara sedang bersaing secara 


\section{$\pi$ (Phi)}

global. Tentunya inovasi tersebut berawal dari pendidikan yang baik. Fakta memberikan gambaran bahwa semua negara maju dapat berkembang pesat karena mereka sangat sadar akan kepedulian terhadap kualitas pendidikan. Oleh karena itu, rasanya kita semua sepakat jika menempatkan pendidikan sebagai faktor penentu tingkat kualitas sumber daya manusia.

Matematika sebagai ilmu dasar yang diajarkan pada setiap jenjang pendidikan, sudah tidak perlu dipertanyakan lagi peranannya dalam perkembangan ilmu pengetahuan dan teknologi serta kehidupan sehari-hari. Mulai rakyat biasa hingga pejabat, balita hingga dewasa, ilmuwan hingga penjahat sekalipun tidak terlepas dari peran matematika. Melihat pentingnya matematika dan peranannya dalam menghadapi kemajuan ilmu pengetahuan dan teknologi serta persaingan global maka peningkatan mutu pendidikan matematika di semua jenis dan jenjang pendidikan harus selalu diupayakan. Salah satu upaya yang dapat dilakukan adalah dengan memperbaiki proses pembelajaran di kelas, agar tujuan pendidikan dapat tercapai dan kemandirian belajar juga meningkat.

Belajar matematika adalah proses dimana matematika ditemukan dan dibangun manusia, sehingga pembelajaran matematika harus lebih dibangun oleh siswa sendiri dari pada ditanamkan oleh guru. Belajar matematika tidak lagi dipandang sebagai proses menerima informasi untuk disimpan di memori siswa yang diperoleh melalui pengulangan praktik (latihan) dan penguatan. Namun, siswa belajar dengan mendekati setiap persoalan baru dengan mengaitkannya dengan pengetahuan yang telah ia miliki, mengasimilasi informasi baru, dan membangun pengertian sendiri.

Berdasarkan hasil wawancara peneliti dengan guru matematika SMP Negeri 1 Siak Hulu di kelas VIII $_{\mathrm{G}}$ pada tanggal 3 Maret 2016, diperoleh informasi bahwa kemandirian siswa masih sangat rendah, siswa belum mandiri dalam belajar dan cenderung guru yang mendominasi dalam pembelajaran. Hal ini disebabkan karena dalam proses pembelajaran guru belum melatih siswa untuk mengerjakan soal-soal secara mandiri, guru juga tidak ada melatih siswa untuk terampil dalam belajar. Siswa tidak dituntut untuk mengevaluasi dan menjelaskan alasan atas jawaban yang diberikan serta dalam belajar siswa tidak dituntut untuk belajar mandiri. Proses belajar mengajar masih didominasi guru, hal ini mengakibatkan kemandirian belajar siswa tidak terbentuk dengan baik sehingga siswa sering sekali mengandalkan guru atau temannya yang lebih mampu memahami materi dalam penyelesaian masalah yang diberikan guru.

Menyikapi permasalahan yang berkaitan dengan kondisi kegiatan pembelajaran di kelas yaitu terkait dengan kemandirian belajar, maka perlu upaya perbaikan dan inovasi dalam proses pembelajaran. Salah satu upaya pembenahan dalam rangka meningkatkan kemandirian siswa difokuskan pada pemberian kesempatan siswa untuk membangun pengetahuannya secara aktif, artinya pengetahuan ditemukan, dibentuk, dan dikembangkan oleh siswa sendiri baik secara individu maupun kelompok dengan menggunakan pembelajaran cooperative learning. Model pembelajaran yang dipilih adalah model pembelajaran kooperatif tipe NHT, dalam NHT para siswa diharapkan dapat saling membantu, saling mendiskusikan dan berargumentasi, untuk mengasah pengetahuan yang mereka kuasai saat itu dan menutup kesenjangan dalam pemahaman masing-masing, sehingga pembelajaran kooperatif tipe NHT dapat meningkatkan prestasi, self-esteem, dan interaksi sosial siswa (Shininger, 2006: 37). Dengan demikian diharapkan kemampuan dan keterampilan siswa dapat meningkat sehingga tercipta pembelajaran yang baik. 


\section{$\pi$ (Phi)}

Salah satu upaya yang dilakukan oleh guru dalam meningkatkan kualitas pembelajaran matematika adalah dengan menggunakan metode Numbered Heads Together (NHT) karena dengan menggunakan metode pembelajaran ini dapat memberi kesempatan kepada anak didik untuk bekerjasama dengan sesama siswa dalam tugas-tugas terstruktur (Lee, 2006:12).

NHT (Numbered Heads Together) pertama kali dikembangkan oleh Spenser Kagen pada tahun 1993 untuk melibatkan lebih banyak siswa dalam menelaah materi yang tercakup dalam suatu pelajaran dan mengecek pemahaman mereka terhadap isi pelajaran tersebut, Selain itu model pembelajaran ini lebih mengutamakan pada aktivitas siswa yaitu mencari, mengolah, dan melaporkan informasi dari berbagai sumber yang nantinya akan dipresentasikan di depan kelas. Pembelajaran kooperatif dalam sintaks NHT guru menggunakan struktur empat fase (Trianto: 2007) yaitu: 1) Penomoran (numbering), 2) Mengajukan pertanyaan (questioning), 3) Berpikir bersama (heads together), 4) Menjawab (answering).

Sedangkan komunikasi Menurut Los Angeles County Office of Education (Ali Mahmudi, 2009: 3) terdapat berbagai bentuk komunikasi komunikasi matematis yaitu a) merefleksi dan mengklarifikasi pemikiran tentang ide-ide matematika; b) menghubungkan bahasa sehari-hari dengan bahasa matematika yang menggunakan simbol-simbol; c) menggunakan keterampilan membaca, mendengarkan, menginterpretasikan, dan mengevaluasi ideide matematika; dan d) menggunakan ideide matematika untuk membuat dugaan (conjecture) dan membuat argumen yang meyakinkan. Brodie (2010: 20) mengatakan bahwa komunikasi merupakan bagian penting dari pemahaman, maka komunikasi digunakan untuk mendiskusikan pemahaman mereka dengan pelajar
lainnya.Matematika merupakan komunikasi dari ide.

Hargies dan Kerlin (Soemarmo, 2013:109) mendefenisikan bahwa kemandirian belajar (Self Regulated Learning) sebagai upaya memperdalam dan memanipulasi jaringan asosiatif dalam suatu bidang tertentu, memantau serta meningkatkan proses pendalaman yang bersangkutan. Berdasarkan definisi tersebut menunjukkan bahwa SRL merupakan suatu perancangan dan pemantauan diri yang seksama terhadap proses kognitif dan afektif dalam menyelesaikan suatu tugas akademik. Sedangkan Bandura (Soemarmo, 2013:109) mendefinisikan SRL sebagai kemampuan memantau perilaku sendiri, dan merupakan keraja keras personaliti manusia. Berdasarkan keterangan di atas, penulis tertarik untuk melakukan penelitian yang berjudul Penerapan Pembelajaran Kooperatif Tipe Number Head Together (NHT) untuk meningkatkan kemandirian belajar matematika siswa SMP”.

\section{METODE PENELITIAN}

Bentuk penelitian ini adalah penelitian tindakan kelas (PTK). Penelitian tindakan kelas disebut juga dengan Classroom Action Research (CAR). Menurut Arikunto, dkk (2008:3), "penelitian tindakan kelas adalah suatu pencermatan terhadap kegiatan belajar berupa sebuah tindakan, yang sengaja dimunculkan dan terjadi pada sebuah kelas secara bersama". Menurut Arikunto (2012: 3) Penelitian Tindakan Kelas (PTK) adalah penelitian yang dilakukan di kelas dengan tujuan untuk memperbaiki berbagai persoalan nyata dan praktis dalam peningkatan mutu pembelajaran di kelas yang dialami langsung dalam interaksi antara guru dengan siswa yang sedang belajar. Seiring dengan iti Endang Istikomah (2009) menuturkan Penelitian Tindakan Kelas merupakan suatu penelitian yang melakukan suatu tindakan berupa melaksanakan pembelajaran dengan melibatkan siswa dalam proses 
pembelajaran dengan mengkonstruksi pengetahuan yang telah dimilikinya. Peneliti ingin melakukan perbaikan dalam pembelajaran matematika di kelas dalam upaya memperbaiki hasil belajar siswa (kemampuan komunikasi) matematika siswa dengan melaksanakan penelitian tindakan kelas.Perancanaan siklus yang akan dilakukan adalah untuk mengetahui keberhasilan dan hambatan dari tindakan yang dilakukan. Penelitian ini memerlukan perencanaan siklus yang terdiri dari empat tahap yang lazim dilalui, yaitu (1) perencanaan, (2) tindakan, (3) pengamatan, dan (4) refleksi. Penelitian ini dilakukan pada kelas VIII $_{\mathrm{G}}$ SMP Negeri 1 Siak Hulu dari tanggal 25 April 2016 sampai $30 \mathrm{Mei}$ 2016.

Instrumen yang digunakan dalam penelitian ini adalah perangkat pembelajaran dan instrumen pengumpulan data. perangkat pembelajaran yang digunakan yaitu Silabus, Rencana Pelaksanaan Pembelajaran (RPP), dan Lembar Aktivitas Siswa (LAS). Instrumen data yang akan dikumpulkan dalam penelitian ini adalahlembar aktivitas guru dan siswa selama proses pembelajaran, data tentang kemandirian belajar siswa dikumpulkan melalui angket kemandirian.

Teknik pengumpulan data pada penelitian ini adalah teknik pengamatan, teknik non tes. Teknik pengamatan dilakukan untuk memperoleh data tentang aktivitas guru dan siswa selama proses pembelajaran yang dilakukan pengamat. Teknik non tes melalui pemberian angket kemandirian belajar kepada siswa yang dilakukan pada setiap ulangan harian yang dilaksanakan pada akhir siklus I dan II.

Teknik analisis data yang digunakan adalah analisis data kuantitatif dan analisis kauntitatif. Dalam penelitian ini data kualitatif didapat dari observasi pengamatan dalam lembar pengamatan. Observasi dilakukan untuk memantau guru dan siswa selama proses pembelajaran yang dicatat dalam lembar pengamatan kemudian data kaulitatif ini akan dianalisis secara deskriptif naratif berbentuk kalimat yang mengambarkan tentang aktivitas guru dan siswa selama proses pembelajaran. Sedangkan analisis kuantitatif dilakukan untuk menganailis hasil angket kemandirian belajar siswa. Keberhasilan tindakan pada penelitian ini dilihat dari skor dasar, ulangan harian I, dan ulangan harian II dianalisis untuk melihat peningkatan kemandirian siswa sesuai dengan indikator kemandirian belajar.

\section{HASIL DAN PEMBAHASAN Analisis Data Kualitatif}

Berdasarkan diskusi peneliti dan pengamat dari hasil pengamatan yang dilakukan selama pembelajaran pada pertemuan 1 sampai dengan pertemuan 8 terlihat bahwa aktivitas guru dan siswa secara keseluruhan belum berjalan dengan baik karena ada kalanya siswa tidak mau berkelompok dan malas diskusi kelompok. Kondisi ini memperlihatkan bahwa kemandirian belajar siswa masih belum terbentuk. Hal ini menyebabkan penguasaan materi yang kurang baik, sehingga berdampak pada rendahnya nilai siswa dalam setiap penilaian khususnya pada ulangan harian.

Pada siklus I dari hasil lembar pengamatan kegiatan pembelajaran belum berjalan dengan baik sesuai dengan perencanaan, hal ini dapat dilihat dari aktivitas guru dan siswa dalam kegiatan pembelajaran dari setiap pertemuan. Pertemuan pertama terlihat guru dan siswa dalam menerapkan model pembelajaran ini masih belum berjalan dengan baik, kekurangan tersebut dapat dilihat dalam berbagai hal seperti pada kegiatan awal, guru terlalu cepat dalam menyampaikan informasi, guru belum melatih siswa untuk belajar mandiri, guru tidak tegas dalam mengatur kelompok sehingga suasana kelas menjadi tidak tenang ketika siswa akan menempati kelompoknya masing-masing, siswa tidak serius mengikuti kegiatan pembelajaran dan terdapat siswa yang 
melakukan aktivitas lain, siswa kurang mandiri dalam dalam aktivitas pembelajaran, hal ini dapat dilihat dari aktivitas guru dan siswa dalam kegiatan pembelajaran dari setiap pertemuan.

Pada pertemuan ke lima dan ke enam terlihat aktivitas guru dan siswa dalam menerapkan model pembelajaran kooperatif dengan metode Numbered Heads Together (NHT) ini sudah mulai berjalan dengan cukup baik, dimana guru lebih tegas dan mampu menguasai kelas. Di sisi lain guru juga sudah membimbing semua kelompok diskusi.. Aktivitas siswa sudah terlihat keseriusan dalam mengikuti pembelajaran dan tidak terlihat siswa yang melakukan aktivitas-aktivitas lain ketika pembelajaran berlangsung. Siswa juga sudah terlihat sungguh-sungguh dalam pengerjaan LAS dalam kelompoknya dan bersemangat untuk bekerja sama dengan pasangannya ketika mencari penyelesaian kartu indeks, kondisi ini tidak terjadi pada setiap pertemuan, beberapa pertemuan terlihat bahwa siswa tidak fokus dan cenderung malas dalam berdiskusi kelompok, setelah diskusi berakhir pun siswa tidak menunjukkan sikap semangat untuk mempresentasikan hasil diskusinya. Tetapi guru selalu berusaha untuk meperbaiki kondisi pembelajaran dengan melakukan refleksi pada setiap pertemuan hingga proses pembelajaran menjadi lebih baik.

Berdasarkan uraian diatas dapat diketahui bahwa aktivitas guru dan siswa pada pembelajaran kooperatif dengan metode Numbered Heads Together (NHT) dari setiap pertemuan pada siklus kedua mengalami peningkatan dari setiap siklus pertama, namun aktivitas siswa cenderung tidak mengalami peningkatan.

\section{Analisis Data Kuantitatif}

Tindakan yang dilaksanakan dalam penelitian ini adalah pembelajaran kooperatif dengan metode Numbered Heads Together (NHT) yang disajikan sebanyak delapan kali pertemuan dalam dua siklus.
Peningkatan kemampuan kemandirian belajar siswa pada siklus I dan siklus II dilihat dari hasil skor dasar ke ulangan harian I, dan ulangan harian I ke ulangan harian II kemandirian belajar siswa kelas VIII $_{G}$ SMP Negeri 1 Siak Hulu. Berdasarkan pengalaman peneliti selama proses pembelajaran berlangsung, aktivitas dan interaksi siswa dalam kelompok sangat baik. Terlihat siswa lebih bersemangat dalam belajar dan lebih partisipasi dalam proses pembelajaran. Dalam mengikuti setiap aktivitas pembelajaran siswa berusaha memahami materi dengan cara bertanya pada teman, bertanya kepada guru, menyimak penjelasan teman yang menyampaikan hasil diskusi. Hal ini juga terlihat dari aktivitas belajar siswa, dimana siswa lebih berani mengeluarkan pendapatnya dalam berdiskusi dan mampu menyelesaikan soal latihan yang ada pada LAS dan pada soal NHT. Peningkatan kemandirian belajar siswa pada siklus I dan siklus II dilihat dari hasil skor ulangan harian I ke ulangan harian II siswa kelas VIII $_{\mathrm{G}}$ SMP Negeri 1 Siak Hulu.

Tabel 1. Kualifikasi tingkat kemandirian belajar siswa secara klasikal pada ulangan harian siklus II dan siklus II

\begin{tabular}{lcc}
\hline \multicolumn{1}{c}{ Uraian } & UH I & UH II \\
\hline Jumlah Skor & 1894,04 & 2710,57 \\
Persentase (\%) & $52,61 \%$ & $75,29 \%$ \\
Kategori & Cukup Mandiri & Mandiri \\
\hline
\end{tabular}

Berdasarkan analisis kemandirian belajar siswa pada Tabel 1 artinya terjadi peningkatan persentase kemandirian belajar siswa pada skor dasar ke UH I, dan UH I ke UH II. Berdasarkan analisis tersebut dapat dikatakan bahwa kemandirian belajar siswa dapat ditingkatkan melaui pembelajaran kooperatif tipe NHT. Selain itu juga terlihat dari jumlah siswa yang mencapai kriteria kemandirian belajar pada kriteria mandiri meningkat dari siklus I ke siklus II mengalami peningkatan dari skor dasar, dimana pada ulangan harian I terdapat 18 orang siswa yang mencapai kriteria mandiri dan pada ulangan harian II terdapat 36 orang siswa yang mencapai kriteria mandiri hingga 


\section{$\pi$ (Phi)}

sangat mandiri. Ini artinya pada siklus II seluruh siswa sudah mandiri dalam belajar. Dengan demikian, dapat disimpulkan bahwa pembelajaran kooperatif dengan metode Numbered Heads Together (NHT) merupakan salah satu cara yang dapat diterapkan guru untuk meningkatkan kemandirian belajar siswa dalam mata pelajaran matematika.

Dengan diterapkannya model pembelajaran kooperatif tipe Numbered Heads Together (NHT) siswa diberi kesempatan untuk melakukan kegiatan berpikir, merefleksi, menyusun dan mengeluarkan ide-ide sehingga setiap setiap mempunyai tugas dan tidak akan terabaikan oleh kelompoknya, ini disebabkan siswa hanya berdiskusi dengan pasangannya. Selanjutnya akan terjalin komunikasi antara siswa dengan siswa, siswa dengan guru, sehingga pembelajaran akan berlangsung efektif dan efisien karena siswa aktif dan bersemangat dalam kegiatan pembelajaran. Dengan demikian akan terbentuk kemandirian belajar siswa.

Dalam pelaksanaan tindakan pada penelitian ini tentu masih terdapat kelemahan-kelemahan yang peneliti/guru lakukan, pada siklus I guru terlalu cepat dalam menyampaikan hal-hal yang ada pada kegiatan awal pembelajaran, begitu juga bahasa yang digunakan guru kurang jelas, sehingga ada siswa yang kurang memperhatikan guru. Namun dalam pelaksanaan siklus II guru/peneliti telah bisa menguasai kelas dan mengelola waktu dengan baik, siswa pun lebih aktif bertanya dalam pembelajaran, karena siswa sudah terbiasa dengan pembelajaran. Kondisi ini membuat aktivitas guru dan siswa berjalan dengan lancar dan sesuai dengan perencanaan, sehingga interaksi antara guru dan siswa berjalan dengan baik.

Berdasarkan uraian di atas, dapat disimpulkan bahwa hasil belajar matematika siswa dapat ditingkatkan dengan pembelajaran Kooperatif tipe Numbered Heads Together (NHT). Jadi, hasil analisis

tindakan ini mendukung hipotesis tindakan yang diajukan yaitu penerapan pembelajaran kooperatif tipe Numbered Heads Together (NHT) dapat memperbaiki proses pembelajaran, dan kemandirian belajar siswa matematika siswa kelas VIII $_{\mathrm{G}}$ SMP 1 Negeri Siak Hulu.

\section{SIMPULAN}

Berdasarkan hasil penelitian dan pembahasan yang telah dikemukakan, maka kesimpulan dari penelitian ini adalah penerapan pembelajaran kooperatif tipe NHT dapat memperbaiki proses pembelajaran dan kemandirian belajar siswa kelas VIII $_{\mathrm{G}}$ SMP Negeri 1 Siak Hulu pada materi bangun ruang sisi datar.

Berdasarkan penelitian yang telah dilakukan, peneliti menyarankan beberapa hal yang berhubungan dengan penerapan model pembelajaran kooperatif tipe NHT sebagai berikut:

a. Dalam proses pembelajaran, guru hendaknya dapat mengatur waktu sebaik mungkin sehingga kegiatan yang direncanakan dapat terlaksana dengan baik.

b. LAS harus dirancang sebaik mungkin dengan langkah-langkah yang mudah dimengerti oleh siswa, sehingga siswa dapat menyelesaikan LAS secara mandiri.

\section{DAFTAR PUSTAKA}

Arikunto, Suharsimi, dkk. 2008. Penelitian Tindakan Kelas. Jakarta: Bumi Aksara.

Arikunto, Suharsimi, dkk. 2012. Penelitian Tindakan Kelas. Jakarta: Bumi Aksara.

Brodie, K. 2010. Teachingmathematical reasoning in secondary school classroom. London: Springer.

Istikomah, Endang. 2009. Peningkatan hasil belajar matematika melalui penerapan Strategi pembelajaran konstruktivis pada siswa Kelas vii ${ }_{4}$ di smp negeri 2 
pasir penyu inhu. Skripsi UIN Susks Riau.

Lee, C. 2006. Language for learning mathematics: assessment fotlLearning in practice. New York: Open University Press.

Mahmudi, Ali. 2009.Komunikasi dalam pembelajaran matematika.Journal MIPMIPA UNHALU volume 8, nomor 1, Februari 2009. http://staff.uny.ac.id/sites/default/files/ penelitian/Ali\%20Mahmudi,\%20S.Pd, \%20MP.d,\%20Dr./Makalah\%2006\%2 0Jurnal\%UNHALU\%202008\%20_Ko munikasi\%20dlm\%20Pembelajaran\% 20Matematika_pdf

Shininger, K. A. 2006, The benefits of using STAD in a middle school mathematics classroom.Diambil tanggal 12 Juli 2015 , dari

www.http://etd.ohiolink.edu/sendpdf.cgi/Shininger\%20Karl\%20A.pdf? def1281639234.

Soemarmo.2013. Berpikir dan Disposisi Matematik Serta Pembelajarannya. Bandung.

Trianto. 2007. Model-Model Pembelajaran Inovatif Berorientasi Konstruktivisme. Jakarta, Prestasi Pustaka 